\title{
Scar Endometrioma Following Cesarian Section: Case Report
}

\author{
Fatih Taskesen ${ }^{\mathrm{a}, \mathrm{c}}$, Suhha Bostanci ${ }^{\mathrm{b}}$, Zulfu Arikanoglu, \\ Omer Uslukaya ${ }^{a}$, Abdullah Oguz ${ }^{\mathrm{a}}$
}

\begin{abstract}
Endometriosis is a gynecological disease which is sometimes presented to general surgeons as a lump at the abdominal wall. It can pose a diagnostic confusion and should be in the differential diagnosis of lumps in the abdomen in female especially with a gynecological abdominal operation history. Endometrioma is well-marked tumoral lesions, such as non-neoplastic granuloma which formed by whitish fibrous tissue, with thick chocolate-like colored liquid areas which composed of endometriosis. This report is about the diagnosis, treatment and prevention of the endometriosis and endometrioma.
\end{abstract}

Keywords: Endometriosis; Endometrioma; Abdominal wall

\section{Introduction}

Term of endometriosis is growth of ectopic endometrial tissue outside of the uterine cavity while extrapelvic endometriosis refers to endometriosis found at body sites other than the pelvis [1]. It can occur in extrapelvic sites, especially in abdominal surgery scars following gynecologic abdominal surgical procedures like hysterectomy and cesarean section, and in the perineum after vaginal deliveries with episiotomy [2]. However, most of the cases reported have occurred following obstetric procedures that exposed the endometrial

Manuscript accepted for publication June 6, 2012

${ }^{a}$ Department of Surgery, Dicle University Hospital, Faculty of Medicine, 21280, Diyarbakir, Turkey

${ }^{\mathrm{b}}$ Department of Obstetrics and Gynecology, Sakarya Education and

Research Hospital, Korucuk, 54100, Sakarya, Turkey

${ }^{\mathrm{c}}$ Corresponding author: Fatih Taskesen, Dicle University School of

Medicine, Department of General Surgery, 21280, Yenisehir, Diyarbakir,

Turkey. Email: drftaskesen@hotmail.com

doi: http://dx.doi.org/10.4021/jcs73w tissue, especially in cases of cesarean section [3-6]. The development of the endometriosis on a surgical scar may have a very late onset after the surgery and its diagnosis often mistaken for a suture granuloma, incisional hernia, abscess or a strange body this situation often predisposes to incorrect diagnosis [4]. The term scar endometrioma is used for wellmarked tumoral lesions, such as non-neoplastic granuloma which formed by whitish fibrous tissue, with thick chocolate-like colored liquid areas, and is located anywhere in the surgical scar [5]. All scar endometriosis is not characterized by endometrioma. When there are no palpable nodules it is hard to diagnose the disease [6]. The treatment for scar endometrioma is surgical removal of the lesion [7].

\section{Case Report}

A 37-year-old woman was presented with a 10-month history of pain during her menstruation at her abdominal scar from a cesarean section three years earlier. On local examination was noticed a painful lump on the lateral aspect of a pfannensteil incision. On ultrasound examination, an $3 \times 3 \mathrm{~cm}$ anisoechogenic nodule with hypoechoic areas enclosed in an area with hyperechogenicity, with a diffuse contour was discovered. Patient was treated surgically, with removal of

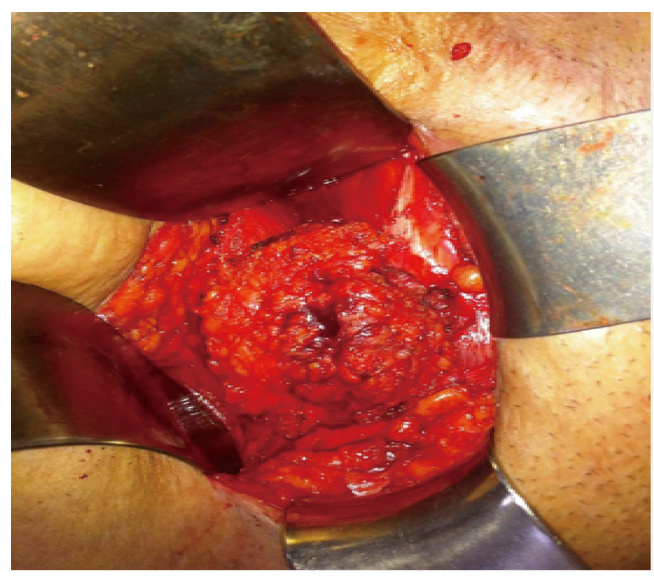

Figure 1. Evidence of endometriona at surgery. 


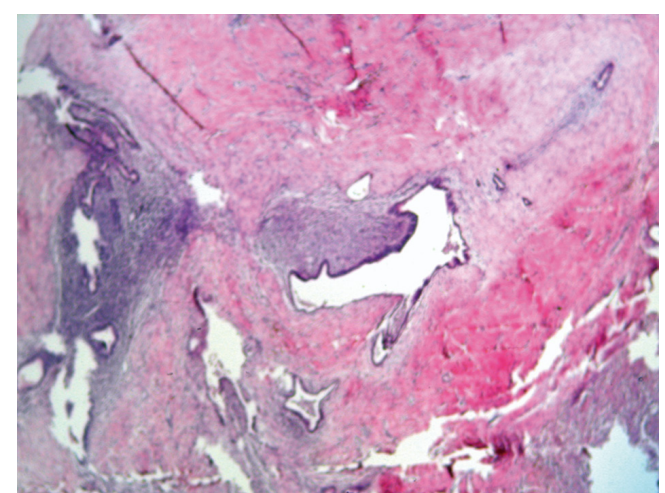

Figure 2. Microphotography of endometrial stroma and gland formations (hematoxylin-eosin x 100).

the endometrioma with a safety margin, with the aiming of achieving a cure and avoiding locoregional recurrence (Fig. 1). Histopathology showed presence of endometrial glands and stromal cells in the connective tissue which confirmed diagnosis of endometriosis abdominal wall scar (Fig. 2).

\section{Discussion}

Endometriosis is the presence of functioning endometrial tissue outside the uterine cavity, whereas endometrioma is a well-circumscribed mass of endometrial tissue. Scar endometriomas are believed to be the result of direct inoculation of the abdominal fascia or subcutaneous tissue with endometrial cells during surgical intervention and subsequently stimulated by estrogen during menstruel cycle to produce endometriomas. In most patients, surgical scar endometrioma involves a painful mass that becomes swollen and more tender before menses. The real incidence of scar endometriosis is difficult to determine, but is estimated at $0.03 \%$ to $0.15 \%$ with the mean period between the procedure and symptoms starting around five years [8]. Failure to close the parietal and visceral peritoneum in the cesarean section may be related to greater rates of scar endometrioma [9].

Excision is the mainstay of treatment of scar tissue endometriomas, and local wide excision to ensure complete removal of the disease is curative. Local recurrence is likely to be after an inadequate surgical excision [10]. Moreover, insufficient excision of the lesion leads to the renewal of the lesion, making it more extensive and destructive. Medical treatment with the use of progestogens, oral contraceptive pills, and danazol is not effective and gives only partial relief in symptoms and does not ablate the lesion [1].

A thorough history and physical examination should always be performed, and surgeons should consider this entity in their differential diagnosis when their patients have symptoms of cyclical pain at the site of incision of abdominal gynecologic surgery procedures especially after cesarean section.

\section{References}

1. Witz CA. Current concepts in the pathogenesis of endometriosis. Clin Obstet Gynecol. 1999;42(3):566-585.

2. Jubanyik KJ, Comite F. Extrapelvic endometriosis. Obstet Gynecol Clin North Am. 1997;24(2):411-440.

3. Bostanci M.S, Yucel A, Akatli A, Sagsoz N. Scar endometriosis after ceserean section: Case Report. J Gynecol-Obstet Neonatal 2006;(3),445-447.

4. Picod G, Boulanger L, Bounoua F, Leduc F, Duval G. [Abdominal wall endometriosis after caesarean section: report of fifteen cases]. Gynecol Obstet Fertil. 2006;34(1):8-13.

5. Meirelles M, Losano R, Viana AT. Endometrioma de cicatriz: estudo de 14 casos [Scar endometriosis: study of 14 cases]. Arq Med Hosp Fac Cienc Med Santa Casa Sao Paulo. 2005;50(3):92-96.

6. Cardenas-Lailson L, Berlanga-Ramirez F, Athie-Athie A, Gonzales-Parada F, Villanueva-Egan L. Endometrioma de pared abdominal: Caracteristicas clinicas y resultados Del tratamiento quirurgico [Abdominal wall endometrioma: clinical characteristics and results of surgical treatment]. Cirujano General. 2002;24(4):295-299.

7. Ding DC, Hsu S. Scar endometriosis at the site of cesarean section. Taiwan J Obstet Gynecol. 2006;45(3):247249.

8. Chatterjee SK. Scar endometriosis: a clinicopathologic study of 17 cases. Obstet Gynecol. 1980;56(1):81-84.

9. Minaglia S, Mishell DR, Jr., Ballard CA. Incisional endometriomas after Cesarean section: a case series. J Reprod Med. 2007;52(7):630-634.

10. Douglas C, Rotimi O. Extragenital endometriosis--a clinicopathological review of a Glasgow hospital experience with case illustrations. J Obstet Gynaecol. 2004;24(7):804-808. 